\title{
ESÉLYEGYENLŐSÉG A VESZPRÉM-BALATON 2023 EURÓPA KULTURÁLIS FÖVÁROSA PROJEKT RENDEZVÉNYEIN
}

\author{
${ }^{1}$ Raffay-Danyi Ágnes $-{ }^{2}$ Ernszt Ildikó \\ ${ }^{1}$ Pannon Egyetem, Turizmus Intézeti Tanszék, egyetemi docens, raffay.agnes@gtk.uni-pannon.hu \\ ${ }^{2}$ Pannon Egyetem, Alkalmazott Gazdálkodástani Intézet, egyetemi docens, \\ ernszt.ildiko@uni-pen.hu
}

DOI: $10.15170 / T V T .2021 .06 .01 .01$

\begin{abstract}
Absztrakt
$\mathrm{Az}$ esélyegyenlőségi törekvéseknek köszönhetően folyamatosan bövül a turizmusban és a szabadidős szolgáltatások fogyasztói között a fogyatékkal élők, vagy egyéb okból speciális igénnyel rendelkezők aránya. Az Európa Kulturális Fővárosa kezdeményezés egyik kulcseleme szintén a széles körü bevonás, így a Veszprém-Balaton 2023 Európa Kulturális Fővárosa projekt horizontális céljai között is a megfogalmazódik az akadálymentesség a fenntarthatóság és a gyermekbarát programfejlesztés mellett. A jelen tanulmány három 2020-ban megrendezett rendezvény kapcsán vizsgálja az esélyegyenlőség egyes kérdéseit, különös tekintettel az akadálymentesítés egyes formáira, valamint a speciális étrendet követők igényeinek kielégítésére, látogatói kérdőíves megkérdezés és szervezőkkel készült interjúk keretében.
\end{abstract}

Kulcsszavak: esélyegyenlöség, akadálymentesség, ételallergia, fenntarthatóság, Európa Kulturális Fövárosa

\begin{abstract}
Due to the equal opportunities initiatives, the number of people with disabilities or with other special needs is constantly growing amongst the consumers of tourism and leisure services. One of the key objectives of the European Capital of Culture initiative also relates to enhancing involvement, and in line with that the Veszprém-Balaton 2023 European Capital of Culture project also declares accessibility as a key horizontal objective, alongside sustainability and child friendly programme development. The study analyses some aspects of equal opportunities, including accessibility and satisfying the needs of people with special dietary requirements at three Veszprém-Balaton 2023 events that were staged in 2020, with the help of a visitor questionnaire survey and interviews conducted with the organisers of the events.
\end{abstract}

Key words: equal opportunities, accessibility, food intolerance, sustainability, European Capital of Culture 


\section{Bevezetés}

$\mathrm{Az}$ esélyegyenlöségi szempontok térnyerésének és a technika fejlődésének köszönhetően folyamatosan bővül a turizmusban részt vevők köre, hiszen a fogyatékkal élők, vagy egyéb okból speciális igénnyel rendelkezők számára is egyre több szolgáltató biztosítja az élményszerzés lehetőségét. Az esélyegyenlőség biztosítása globális kérdés is egyben, mely áthatja az ENSZ által elfogadott Agenda 2023 fenntarthatósági keretrendszer céljait is. Az Európai Kulturális Főváros (továbbiakban EKF) kezdeményezés céljai között is fontos szerepet kapnak a fenntarthatósági és esélyegyenlőségi szempontok, csakúgy, mint a tágan értelmezett kultúra fogyasztói körének kiszélesítése. Az esélyegyenlőség biztosításával tehát a fenntarthatósági célok és a kultúrafogyasztók körének bővítése egyszerre valósulhat meg. A Veszprém-Balaton 2023 Európa Kulturális Fővárosa projekt (továbbiakban VEB2023) nagy hangsúlyt fektet arra, hogy a megvalósuló programok a lehetőségekhez mérten a legtöbb ember számára elérhetőek legyenek. Ezen célkitüzés megvalósulásának egyes elemeit már meg is tapasztalhatta a nagyközönség a VEB2023 támogatásával, vagy annak szervezésében 2020-ban megvalósult rendezvényeken. A jelen tanulmány az Utcazene Fesztivál, a Köfeszt, valamint a Veszprém-Balaton Filmpiknik látogatói és szervezői körében vizsgálja az esélyegyenlőség egyes kérdéseit. A kutatás az alábbi kérdésekre keresi a választ:

\begin{tabular}{|l|l|}
\hline K1 & Esélyegyenlőségi problémák jelenléte a rendezvényen \\
\hline K2 & Fesztiválhelyszín akadálymentessége speciális célcsoportok szempontjából \\
\hline K3 & Ételallergiás/vegetáriánus/vegán résztvevők igényeinek kiszolgálása \\
\hline K4 & $\begin{array}{l}\text { Az ételkínálat és az ételallergiások, speciális étrendet követők igényeinek } \\
\text { összhangja }\end{array}$ \\
\hline
\end{tabular}

A kutatási kérdések megválaszolásához strukturált interjúk készültek a rendezvények fő szervezőjével és a szervezői csapat további érintett tagjaival, valamint kérdőíves felmérés segítségével mértük fel a rendezvények látogatóinak véleményét és percepcióit.

\section{Szakirodalmi áttekintés}

\subsection{Veszprém-Balaton 2023 Európa Kulturális Fővárosa projekt horizontális céljai}

Az Európai Unió 1985-ben indította el az Európa Kulturális Városa programot azzal a céllal, hogy elősegítse a kulturális örökség sokszínűségének bemutatását és megőrzését, valamint ezzel egyidejűleg az európai népek egymáshoz való közeledését. (Raffay - Lőrincz 2018). Az Európa Kulturális Fővárosa projekt az Európai Unió kultúrpolitikájának egyik legsikeresebb kezdeményezésének tekinthető: az elmúlt évtizedek során bebizonyosodott, hogy a kulturális élet élénkítése, a gazdaság- és városfejlesztés mellett az esemény jelentős turisztikai hatással is bír a címet birtokló városra illetve térségére (Lőrincz 2017).

Hazánkban elsőként Pécs viselhette a megtisztelő címet, 2010-ben 2023-ban pedig Veszprém városa a Balaton régióval karöltve képviseli Magyarországot az Európai Kulturális Fővárosok sorában. A Veszprém-Balaton 2023 Európa Kulturális Fővárosa projekt horizontális céljai között a fenntarthatóság és a gyermekbarát programfejlesztés megfogalmazódik az akadálymentesség is, a projekt keretében nagy hangsúlyt fektetnek arra, hogy a megvalósuló programok a lehetőségekhez mérten a legtöbb ember számára elérhetőek legyenek. „Fontos, hogy a fogyatékossággal élő személyek mellett az idősek, babakocsival érkező családok, külföldi vendégek is megtalálják a saját programjaikat az eseményeinken. Mi elsősorban a programok akadálymentesítésén dolgozunk, mely egy hosszú folyamat része” (filmpiknik.hu). 


\subsection{Fenntartható fejlődés és esélyegyenlőség}

AZ ENSZ 2015-ben fogadta el az új integrált fenntartható fejlődési keretrendszert, az Agenda 2023-at, mely fó célkitüzései a szegénység elleni küzdelem, az egyenlötlenségek leküzdése, valamint a Föld környezeti rendszerének a megóvása. Az Agenda 203017 pontba rendezve fogalmazza meg a fenntartható fejlődés gazdasági, környezeti és társadalmi dimenzióinak az egyensúlyára építő célkitüzéseket. Az esélyegyenlőség kérdése több célban is megjelenik, de a fogyatékkal élők esélyegyenlősége nem jelenik meg hangsúlyosan. A befogadó társadalom, mint cél nem tér ki a fogyatékkal élők esélyeinek egyenlőségére vagy egyenlőtlenségére, pedig az élet számos területén, valamint a turizmusban is jelentős hátránnyal szembesülnek azok a személyek, akik valamilyen fogyatékossággal élnek együtt (Gillovich - McIntosh 2020).

\subsection{Fogyatékkal élők, mint turisztikai szegmens}

Az Európai Bizottság egy 2013-as jelentése arra hívja fel a figyelmet, hogy várhatóan emelkedni fog a fogyatékkal élők száma a következő évtizedekben. Ennek egyik oka a várható élettartam növekedése, minek következtében többen érik el azt a kort, melyben jellemzően megnő a mozgásszervi és érzékelési fogyatékosságok előfordulásának gyakorisága, valamint az is, hogy az orvostudomány fejlődésének köszönhetően a fogyatékkal született gyermekek nagyobb eséllyel maradnak életben. Ezek a fogyatékossággal élő személyek - és családtagjaik - várhatóan megjelennek a turisztikai fogyasztásban is, melyhez hozzájárul az is, hogy az új technológiák új lehetőségeket is teremtenek a fogyatékkal élők számára. A speciális igénnyel rendelkező szegmensek megjelenésével új piaci lehetőségek nyílnak meg többek között a turisztikai és kulturális szektorban is (Leidner - Bender 2007). Dwyer - Darcy (2011) más szemszögböl is megközelíti a kérdést, véleményük szerint a fogyatékkal élők egyrészt piaci szegmenst jelentenek, másrészt viszont minden egyes piaci szegmens részeseiként is tekinthetünk rájuk. Mindkét nézőpontból tekintve elmondható, hogy a fogyatékkal élöknek ugyanúgy joga van a desztinációkhoz és azon belül a turisztikai attrakciókhoz és szolgáltatókhoz való hozzáféréshez, ahogy az ENSZ 2006-s deklarációja is megfogalmazza. Darcy - Dickson (2009) a hozzáférésen túl a pozitív desztinációban szerzett tapasztalatok előfeltételeként a függetlenség, egyenlőség és méltóság értékeket is nevesíti, mint a szolgáltatások nyújtásának alappilléreit. Továbbmenve, Zhelyazkova et al. (2007) ezeket a fenntartható fejlődés alapfeltételeinek is tekinti. Összegezve elmondható, hogy a fogyatékkal élők és egyéb speciális igényekkel rendelkezők bevonása a turizmusba tehát nem csak társadalmi kötelezettség, hanem jelentős üzleti potenciál is egyben (Kastenholz et al. 2015, Teixeira et al. 2019).

\subsection{Akadálymentes turizmus}

Az akadálymentes turizmusnak ugyan nincs általánosan elfogadott definíciója, de számos megfogalmazás utal azokra az elemekre, melyek a fogyatékkal élő csoportok turizmushoz való hozzáférését lehetővé teszik vagy segítik (Darcy - Dickson 2009, Zsarnóczky 2018, Farkas Petykó 2019, Raffay - Gonda 2020). Az akadálymentes turizmus hozzáférést biztosít tehát turisztikai szolgáltatásokhoz, kulturális és szabadidős tevékenységekhez, az egyenlőség, az autonómia és az lehetőségének megteremtésére törekedve, valamint az emberi méltóságot szem elött tartva (Darcy 2010).

Mivel a fogyaték sokféle formát ölthet, a fogyatékkal élök szükségletei is meglehetősen változatosak, így ezeket nem lehet egységesen kezelni. Lehetnek olyan problémák, mellyel bármely utazó szembesülhet, míg olyanok is, amik csak szük szegmens számára jelentenek akadályt (Shaw - Coles 2004, Buhalis - Michopoulou 2013, McKercher - Darcy 2018). 
Az akadálymentesség messze túlmutat a fizikai akadályok eltávolításával biztosított hozzáférhetőségtől: a magas szintü élményszerzés biztosításához szükséges feltételek megteremtését jelenti, beleértve a látás-vagy hallássérültek, vagy értelmi fogyatékkal élők számára is hozzáférhető és élvezhető turisztikai attrakciók, szabadidős tevékenységek és egyéb szolgáltatások nyújtását. Ugyanígy a speciális étrendet követő látogatók számára is akkor lesz teljes az élmény, ha a turisztikai-szabadidős szolgáltatások igénybevétele során az étkezési igényeit is kompromisszumok nélkül ki tudja elégíteni.

Az akadálymentes turizmus feltételeinek kialakítása nem csak a fogyatékkal élők számára teszi elérhetővé a turisztikai szolgáltatásokat, sok esetben más olyan csoportok is élvezhetik ennek előnyeit, akik ugyan nem élnek fogyatékkal, de egyéb tényezők miatt könnyebbséget jelenthet számukra például a fizikai akadálymentesítés (Gondos 2020). A koruknál fogva nehezebben mozgó idősek, vagy a kisgyermekkel, föképp babakocsival közlekedő családok is nyertesei a helyszínek és szolgáltatások akadálymentes kialakításának.

\subsection{Speciális étkezési igények}

Ahogy a fizikai akadálymentesítés, úgy a különleges étrenddel rendelkező vendégek igényeinek kielégítése is egyre nagyobb elvárás a nagyközönség részéről. Részben az ételallergiával, ételintoleranciával rendelkező emberek számának a növekedésének (BENEDÉ ET AL, 2016), részben pedig az egészség- és környezettudatos magatartás térnyerésének köszönhetően jelentősen megváltoztak az étkezési szokások a 21. században. Bizonyos élelmiszercsoportok (például húsfélék, tejtermékek) fogyasztásában jelentős csökkenés, másokéban (zöldségfélék, növényi alapú italok, gluténmentes termékek) pedig növekedés tapasztalható. A brit Vegan Society felmérése szerint Nagy Britanniában például a fogyasztók 35\%-a tudatosan hagyja el a húst egyegy nap vagy egy meghatározott időre, a vegán étrendet követők száma pedig négyszeresére nőtt a 2014- és 2018 közötti időszakban (Plant Menu, limevenueportfolio.com). Világszerte hasonló trendek tapasztalhatóak: az Egyesült Államokban is hatszorosára növekedett a vegánok száma 2017 és 2017 között; 2017 júliusa és 2018 júniusa között Németország világelső volt a vegán termékek kifejlesztésében és piacra vitelében, és Dél-Kelet Ázsiában is többszörösére nőtt a vegetáriánus és vegán termékek kínálata 2012 és 2016 között.

A Nielsen kutatása szerint Magyarországon a lakosság csaknem harmada küzd valamilyen ételallergiával, illetve ételintoleranciával - ami jelentősen több, mint a $22 \%$-os európai átlag. A legtöbben a laktózra érzékenyek, de a glutén, szója is a fö allergének között jelenik meg. A fogyasztókat ez alapvetően befolyásolja, és 68\%-uk még többet is hajlandó fizetni olyan élelmiszerekért, amelyek mentesek az olyan összetevőktől, amelyeket kerülni szeretnének. Ez a tudatosság abban is megmutatkozik, hogy ugyancsak ilyen arányban megvizsgálják, hogy milyen alkotóelemei vannak egy terméknek, és ha csak lehetőségük nyílik rá, a többség a magyar termékek mellett dönt (MEDICALONLINE, 2017).

LORGER - ZSARNÓCZKY kutatása arra mutatott rá, hogy sokan kerülnek bizonyos allergéneket még akkor is, hogy a szervezetük jól tolerálja őket - pusztán az egészségtudatosság jegyében: a válaszadók mintegy 52\%-a nyilatkozott így. Jelentős mértékben meghatározza egy családtag ételallergiája, intoleranciája azt is, hogy a család melyik éttermet választja a válaszadók elsöprő többsége $(72 \%)$ szerint (LORGER - ZSARNÓCZKY 2019). SALKOVA - TICHA kutatásuk alapján azt tárták fel, hogy ugyan a társadalom tagjai körében egyre gyakoribb a glutén érzékenység, a vendéglátóipar nem igazán van felkészülve az ellátásukra, szükséges lenne a számukra is megfelelő ételek választékát növelni (SALKOVA - TICHA 2020). Továbbá azok, akik valamilyen különleges étrendet követnek, sok esetben kell meglehetősen negatív hozzáállást elszenvedniük mások részéről. Ilyen esetekben pszichés következményekkel is szembe kell nézniük: magányosnak érzik és szégyellik magukat. Az is előfordul, hogy tehernek érzik saját maguk problémáját a mások számára, és folyamatosan szembe kell nézniük az allergéntől való félelmükkel is. 
A helyzetet tovább rontja az, hogy sokszor az éttermek személyzete sem rendelkezik megfelelö információval az ételallergiában és intoleranciában szenvedő csoportokról és különleges igényeikről (EREN 2020, PRATTEN - TOWERS 2003, SVERKER ET AL. 2005). Sok éttermi alkalmazott nem kapott semmiféle képzést ezzel kapcsolatban, de az önállóan ütemezhető képzési programokat a legtöbben szívesen fogadnák, amelyek valódi, életből vett példákkal, egyszerü nyelvezeten adnak információt a kérdésről (LEE - SOZEN 2016).

Annak ellenére, hogy általában véve pozitívan állnak a vegetarianizmushoz és a vegetáriánus ételekhez a hotelek, nincs külön vegetáriánus étlap a hotelek kínálatában, sem pedig külön az ilyen jellegü ételek készítésére nem alkalmaznak külön személyzetet (IKIZ -SOLUNOGLU 2018).

\section{A Veszprém-Balaton 2023 projekt kiválasztott rendezvényeinek bemutatása}

\subsection{Kőfeszt - a Nyugalom Fesztiválja}

2019-ben rendezte meg első alkalommal a Határtalan Hangok Alapítvány Kövágóörsön a Köfeszt elnevezésü fesztivált, ami Cseh Tamás halálának a 10. évfordulójának is emléket állított. Egy olyan összmüvészeti fesztivált szerveztek, amelyben helyet kapott mind a képzőmüvészet, a színház, a zene; de kerekasztal beszélgetéseket is tartottak. A felnőttek mellett a gyerekekre is gondoltak: kreatív, képességfejlesztő fajátékokkal teli játszóház várta őket a szabadban; emellett gyermek táncház, interaktív mesejáték koncert is szórakoztatta őket.

2019-ben még azt tüzték ki célul a szervezők, hogy „Kővágóörs visszakerüljön a kulturális térképre", ebben az évben a település mellett Salföldön szerveztek még programokat, 2020-ban már a Káli-medence hét települése vett részt a programsorozatban. (Köfeszt 2019:3, Köfeszt 2020). A fesztivál sikerét mutatja az is, hogy a járvány ellenére is képes volt növekedni: amíg az első évben még 25 programot kínált, és 2500 látogatója volt, addig a 2020-as évben már 149 programot ajánlott, és 7700 látogatóval büszkélkedhetett (Köfeszt 2020).

A szervezők filozófiájaként is felfogható az alábbi megfogalmazás: „,a minőségi magyar kultúrát mutatjuk be úgy, hogy ez a hagyományápoló kulturális rendezvénysorozat azoknak szól, akik nem öncélúan bulizni akarnak, hanem mosolyogni, hogy a helyi közösségépítéshez az is hozzátartozik, hogy az itt élők bekapcsolódnak a programokba, teret adunk az elképzeléseiknek." (Köfeszt 2020:7).

\subsection{Utcazene Fesztivál}

A Veszprémi Utcazene Fesztivál Magyarország első számú utcazene fesztiválja, mely 2000 óta több tízezer ember szórakoztatásáról gondoskodik. Az ingyenes rendezvény minden év július második felében, szerdától szombatig kerül megrendezésre. Veszprém történelmi óvárosa, valamint a belváros utcái terei szolgálnak a fesztivál helyszínéül. Délutántól, kora estig előzetesen kiválasztott utcazenészek lépnek fel, és versengenek négy napon keresztül a szakmai és a közönség díjért, a késő esti óráktól pedig nemzetközi fellépők és elismert utcazenészek kövezik őket.

2015-től Az Utcazene Fesztivál sikeresen elörelépett a gasztronómia területén is, hiszen vidéken elöször itt mutatkozott be a Food Truck Show, melynek elsődleges célja, hogy minőségi ételeket, italokat kínáló, mozgásra képes vendéglátó jármüveket sorakoztasson fel térben és időben koncentráltan. A változatos alapanyagokból készülő ételek mellett kézmüves szörpökkel, sörökkel, pálinkákkal és borokkal is találkozhatnak itt a fesztivállátogatók. 
2020-ban a koronavírus járványnak köszönhetően az utolsó pillanatig kérdéses volt, hogy egyáltalán megrendezésre kerül-e a fesztivál. A járványügyi szabályozásnak megfelelve egy szükített rendezvénnyel jelentkezett az Utcazene Fesztivál, kisebb kínálattal, de helyet kapott a fesztivál mára már szerves részét képező Food Truck Show, mint gasztrorendezvény, valamint naponta 18:00 és 00:00 között 4 utcazenész ponton bemutatkozási lehetőséget kaptak az utcazenész verseny idei évre kiválogatott 20 elöadója. 2020-ban a rendezvény csak Óváros téren a közvetlen környezetébe levő utcákban zajlott.

\subsection{Veszprém-Balaton Filmpiknik}

A Veszprém-Balaton 2023 Európa Kulturális Fővárosa program első saját rendezvénye a Veszprém-Balaton Filmpiknik, mely 2020 szeptemberében azzal a céllal került lebonyolításra, hogy a hazai közönség Veszprémben és a Balatonon nézzen magyar filmeket, találkozzon magyar sztárokkal és filmkészítőkkel, fedezzen fel vagy nézzen újra kortárs és klasszikus remekmüveket, közönségfilmeket és filmcsemegéket. A rendezvény további célja, hogy fórumot teremtsen a magyar filmszakmának, és az is, hogy Veszprém és a Balaton kulturális-kreatív régiója erősödjön, és európai láthatósága növekedjen.

A Filmpiknik az Európa Kulturális Fővárosa 2023 program, a Nemzeti Filmintézet és a Magyar Filmakadémia szoros együttmüködéséből született meg (veszprembalaton2023.hu) A vetítések több helyszínen zajlottak három napon át: Veszprémben a Hangvilla Multifunkcionális Közösségi Tér színháztermében, a hozzá tartozó Expresszó klubhelységben, valamint szabadtéren a Várban található Szentháromság téren; Balatonfüreden a Balaton Moziban, valamint a Tagore sétányon kialakított szabadtéri helyszínen. A Filmpiknik egyben egy kötetlen találkozóhelyet is igyekezett biztosítani a szereplőknek, filmkészítőknek és a közönségüknek egyaránt. Kísérő rendezvényként a Filmpiknik Café teremtette meg ezt a találkozóhelyet Veszprém történelmi központjában, ahol koncertek és igazi bistro hangulatot sugárzó tapas bár biztosított további szórakozási lehetőségeket.

\section{Módszertan}

\subsection{Kérdőíves felmérés}

A három rendezvényen kérdezőbiztosok segítségével került lekérdezésre egy fenntarthatósági kérdéseket tartalmazó, papír alapú kérdőív, azzal a céllal, hogy felmérje a helyi rendezvényeket látogatók szokásait, valamint azt, mennyire tud megfelelni egy rendezvény a látogatók, lakosok, dolgozók, fellépők elvárásainak. A válaszok segítik a fesztiválszervezők munkáját, hogy a jövőben ezek alapján tudják alakítani fenntarthatósági intézkedéseiket.

A rendezvények látogatottságbeli különbsége a kitöltött kérdöívek számában is megmutatkozik: a Balaton-felvidék kis falvaiban helyet kapó Kőfeszten 156-an, a Bakony-Balaton Filmpikniken 167an, az Utcazene Fesztivál látogatói közül pedig 452-en töltötték ki a kérdőívet. Nem minden kitöltés teljes, így az egyes válaszoknál az adott kérdésre kapott válaszok számát vesszük alapul az arányok bemutatásánál. A jelen tanulmányban a válaszok gyakoriságát mutatjuk be rendezvényenként.

\subsection{Mélyinterjúk a rendezvények szervezőivel}

A fenntarthatósági szempontok megismeréséhez félig strukturált interjúk készültek a rendezvények szervezésében érintett szereplőkkel. Minden rendezvény esetén három-négy interjúalany került kiválasztásra. A fő szervező(k) mellett fontosnak tartottuk a fenntarthatóság egyes aspektusaihoz kapcsolódó területekért felelős további szervező véleményének megismerését is. 
Az interjúkérdések között a fesztiválok fenntarthatóságról általánosságban alkotott véleményük, a fenntarthatóság irányába tett eddigi lépések, a szolgáltatók és beszállítókkal szembeni fenntarthatósági szempontok, a szemléletformálás, a helyi lakosság bevonása, az esélyegyenlőség - beleértve az akadálymentesség kérdése, a dolgozókkal való bánásmód, a környezetvédelem és a látogatói biztonság különböző aspektusai szerepeltek. Az interjúalanyok személyes véleményének tiszteletben tartásával a válaszokat témakörönként összesítve mutatjuk be, a konkrét rendezvényt abban az esetben nevesítjük, amikor a kontextusba helyezés segíti a megértést.

\section{Eredmények}

\subsection{Kérdőíves felmérés eredményei}

A kérdőíves felmérés a fenntarthatóság különböző vetületeire kereste a választ a fesztiválok résztvevőitől. A jelen tanulmány szempontjából az esetleges esélyegyenlőségi problémák érzékelésére (beleértve az akadálymentességet), az ételallergiára és speciális étkezési igényekre, valamint az étkezési preferenciáknak megfelelö kínálatra vonatkozó kérdésekre adott válaszok kerülnek bemutatásra.

\subsubsection{Esélyegyenlőségi problémák percepciója}

A kérdőív jelen tanulmány szempontjából fontos egyik kérdése az esélyegyenlőségre, mint érzékelt problémára irányult. A válaszadóknak 1-től 4-es skálán kellett megítélniük, hogy az esélyegyenlöség problémája (pl. akadálymentesség) mennyire van jelen a rendezvényen. Az 1-es érték a 'nincs jelen', a 2-es a 'kicsit jelen van', a 3-as az 'erösen jelen van', míg a 4-es a 'komoly problémát okoz' válaszokat jelölte. Az alábbi diagramok alapján megállapítható, hogy egyik rendezvényen sem érzékelték ezt komoly problémának a válaszadók.

\section{1. Ábra: Az esélyegyenlőségi problémák érzékelése a Kőfeszt látogatói körében}

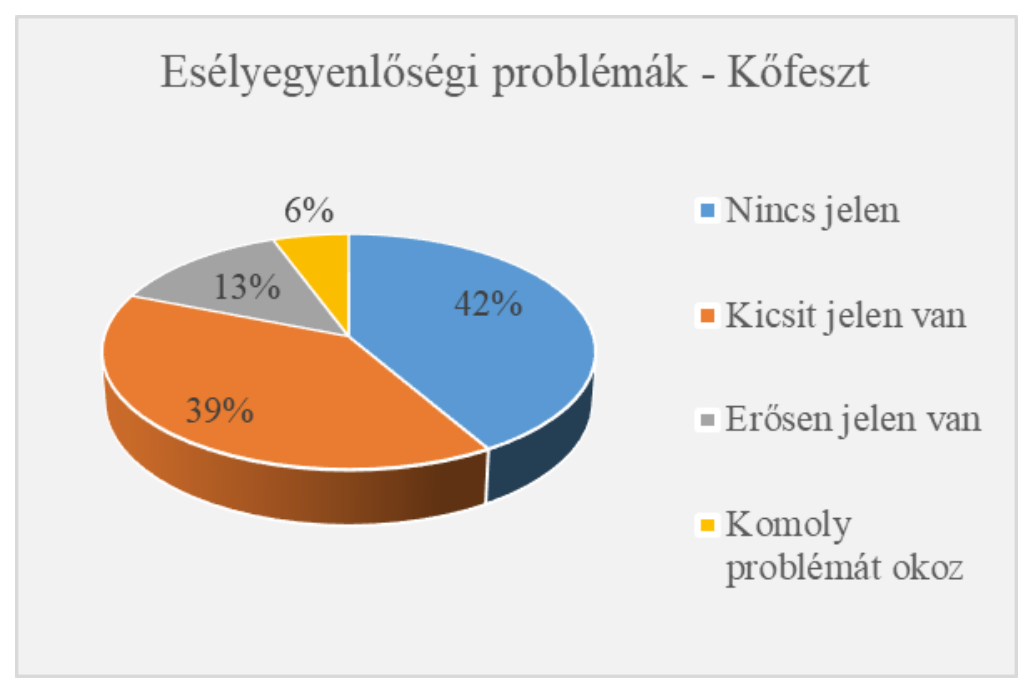

Forrás: saját szerkesztés (2021)

A válaszok alapján feltételezhető, hogy a helyszíni adottságok is valamelyest befolyásolják az esélyegyenlőség problémájának, beleértve az akadálymentesség problémájának az érzékelését az egyes rendezvényeken, hiszen a kisebb településeken megrendezett Köfeszten érezték kevesebben azt (42\%), hogy a probléma egyáltalán nincs jelen. 


\section{2. Ábra: Az esélyegyenlőségi problémák érzékelése a Filmpiknik látogatói körében}

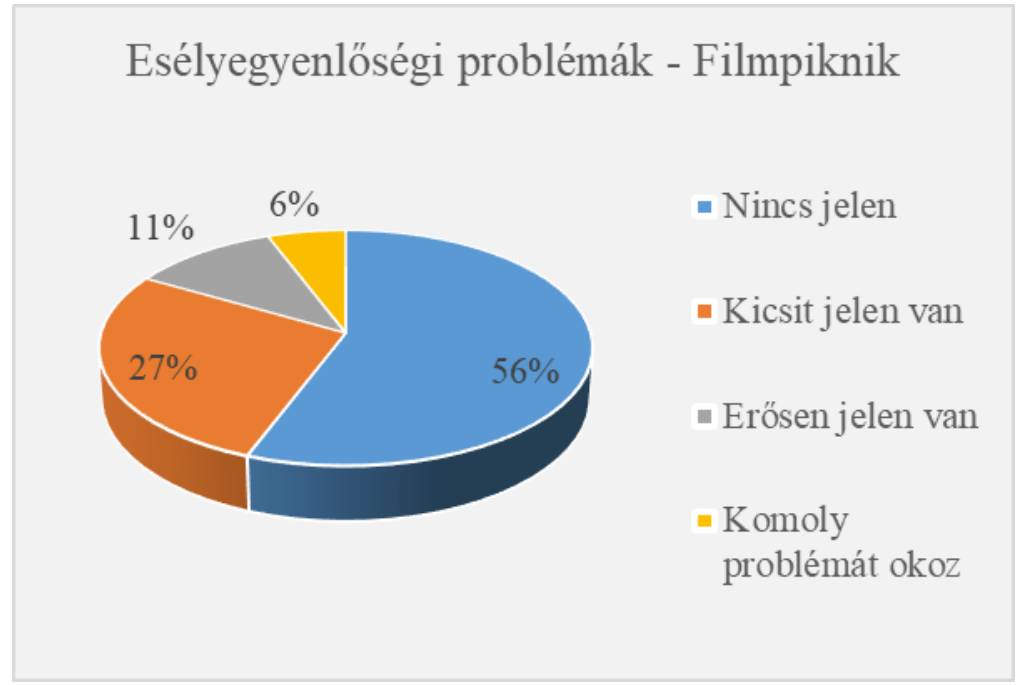

Forrás: saját szerkesztés (2021)

Ahogy a diagram is mutatja, a (fizikai) akadálymentességet eleve biztosító beltéri helyszíneken (közösségi térben, moziban) is zajló Filmpikniken jelölte a legtöbb válaszadó, hogy az esélyegyenlőség, akadálymentesség problémája egyáltalán nincs jelen.

\section{3. Ábra: Az esélyegyenlőségi problémák érzékelése az Utcazene Fesztivál látogatói körében}

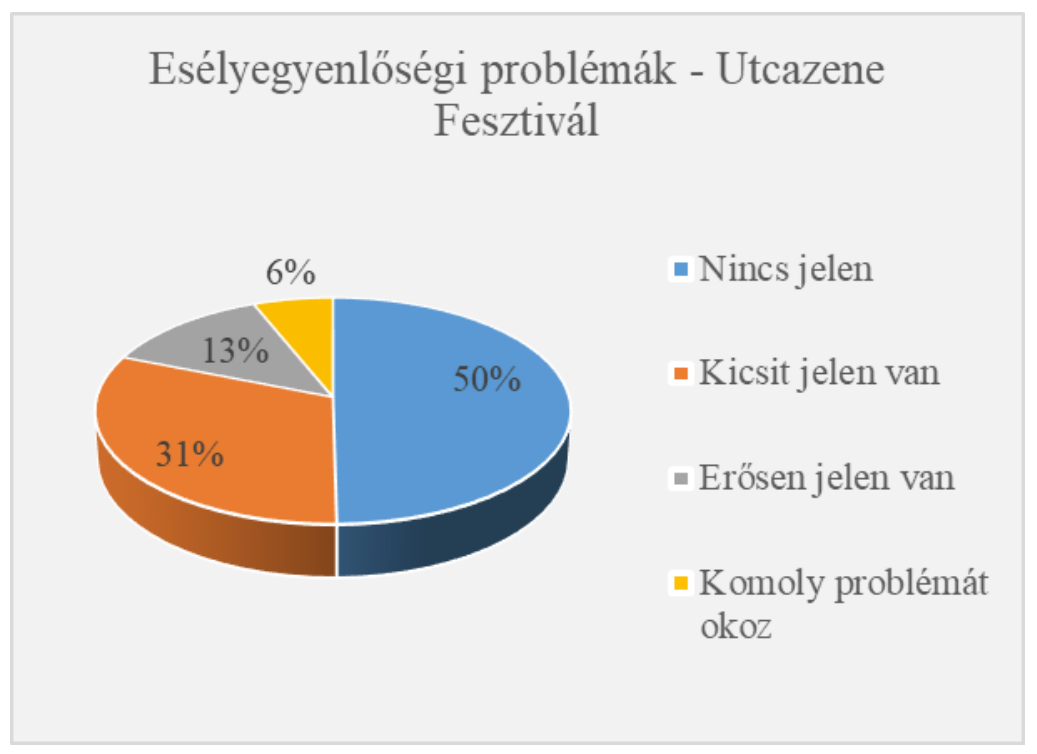

Forrás: saját szerkesztés (2021)

Az Utcazene Fesztivál látogatóinak válaszai arra utalnak, hogy az esélyegyenlőség, akadálymentesség problémája egyáltalán nincs, vagy csak kis mértékben van jelen a fesztiválon.

4.1.2. Ételallergia és speciális étkezési igények

Mindhárom fesztivál válaszadói között szerepeltek olyanok, akiknek van valamilyen ételallergiájuk: a Kőfeszt látogató-válaszadói körében 9,6\% jelzett ételallergiát, az Utcazene Fesztiválon 15,56\%, míg a Veszprém-Balaton Filmpikniken a válaszadók 11,65\%-a rendelkezik valamiféle ételallergiával. 
$\mathrm{Az}$ esélyegyenlőség szempontjából fontos volt arra a kérdésre is választ kapni, hogy az ételallergiával rendelkező válaszadók mennyire elégedettek a rendezvényen kapható ételek választékával az étkezési szükségleteik, preferenciáik szempontjából. 1-től 4-ig terjedő skálán kellett értékelniük a kínálatot, ahol az 1-es az egyáltalán nem talál a hétköznapi étrendjének és ételallergiájának megfelelő kínálatot, a 4-es pedig a nagy választékot jelölte. Az alábbi diagramok mutatják a válaszokat (4. Ábra, 5. Ábra, 6. ábra):

\section{4. Ábra: Az ételkínálat értékelése a Kőfeszt ételallergiával rendelkező válaszadói körében}

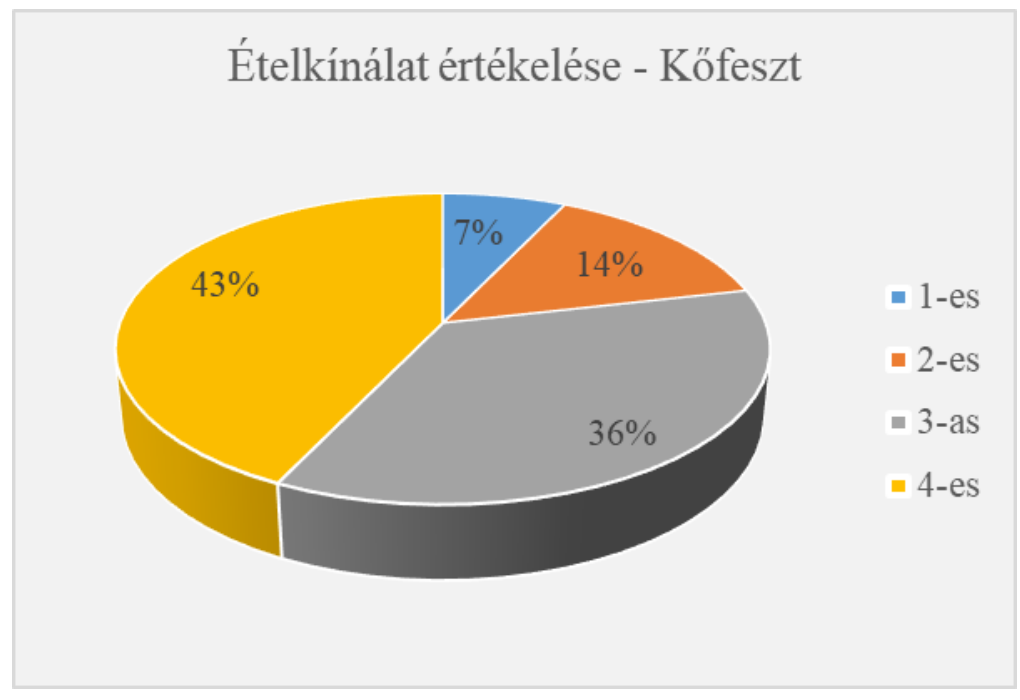

Forrás: saját szerkesztés (2021)

Amint az 1. Ábra mutatja, a válaszadók jellemzően elégedettek voltak a kínálattal, a válaszadók 43\%-a jelölte a nagy választék opciót, míg összesen $7 \%$-uk jelezte, hogy nem talál az ételallergiájának és hétköznapi étrendjének megfelelő kínálatot.

\section{5. Ábra: Az ételkínálat értékelése a Filmpiknik ételallergiával rendelkező válaszadói körében}

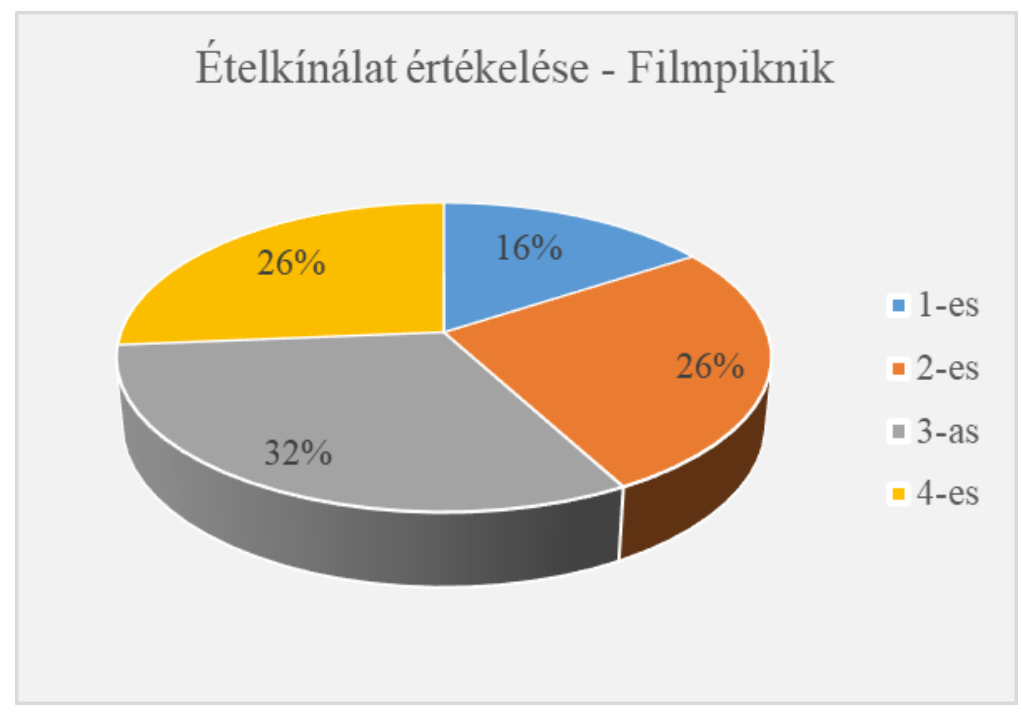

Forrás: saját szerkesztés (2021) 
A Veszprém-Balaton Filmpiknik ételallergiával rendelkező válaszadói meglehetősen vegyesen értékelték az ételkínálatot: a három vizsgált rendezvény közül itt jelezték legtöbben, hogy nem találnak az igényeiknek megfelelö kínálatot, a 2-es, 3-as, 4-es értékekre adott válaszok megoszlása pedig közel azonos.

\section{6. ábra: Az ételkínálat értékelése az Utcazene Fesztivál ételallergiával rendelkező válaszadói körében}

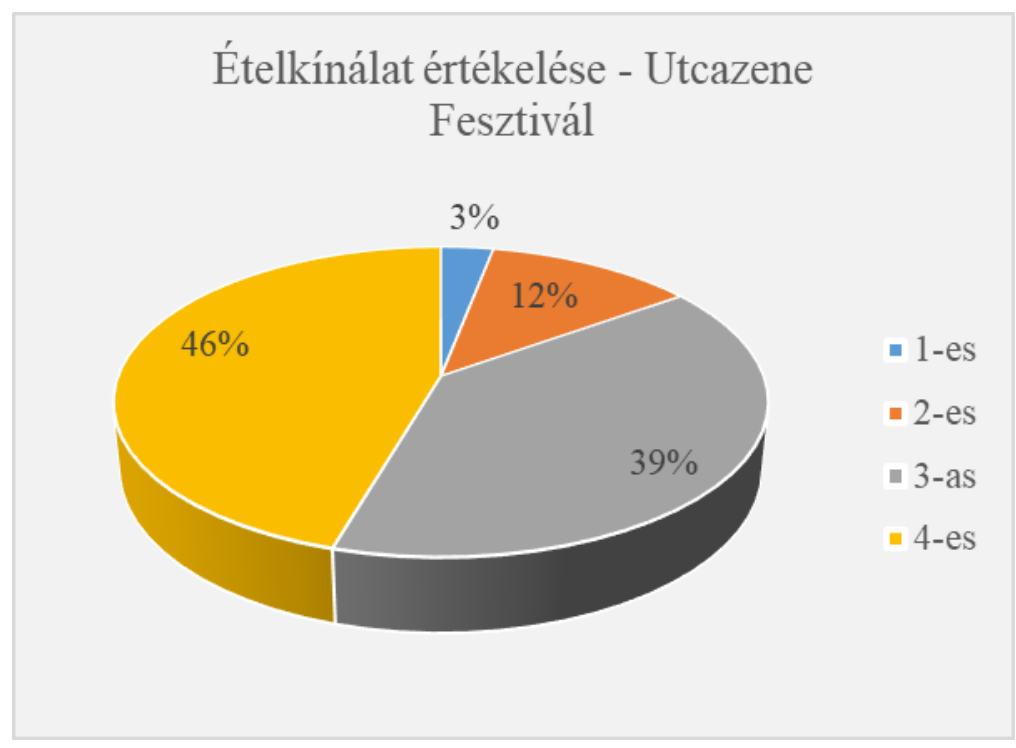

Forrás: saját szerkesztés (2021)

Az Utcazene Fesztiválon kapott értékek bemutatásakor meg kell említeni, hogy a fesztivál része, kiegészítő eleme a Food Truck Show, így nem a zenei rendezvény szervezőinek a kompetenciája az ételallergiával vagy étkezési preferenciával rendelkező látogatóik igényeinek a kielégítése, a Food Truck Show szervezői foglalkoznak ezzel a kérdéssel. A Food Truck Show szervezői foglalkoznak ezzel a kérdéssel, akik már a catering szolgáltatók kiválasztásakor igyekeznek olyan kínálati palettát összeállítani, hogy a különböző étkezési igényeket minél nagyobb mértékben ki tudják elégíteni.

A válaszok között külön vizsgáltuk a speciális (vegetáriánus, vegán) étrendet folytató válaszadók kínálattal való elégedettségét is. A speciális étrendet jelölő látogatók aránya a mintában elenyésző, 2-5\% között volt a vegetáriánus válaszadók száma a három rendezvényen, míg a vegán étrendet összesen hat válaszadó jelölte a három rendezvény 775 válaszadója közül. A speciális étrendet folytatók jellemzően elégedettek voltak a kínálattal, minden rendezvény esetében a legpozitívabb 4-es érték volt a jellemző (18 válaszadó), 1-es értéket összesen egyetlen válaszadó jelölt. Az alacsony elemszám miatt az eredményeket diagramon nem ábrázoljuk.

\subsection{Szervezőkkel készült interjúk válaszai}

Az interjúk során az esélyegyenlőség témakörén belül azt vizsgáltuk, a fesztivál szervezői mennyire igyekeznek, illetve tudnak megfelelni a fogyatékkal élők vagy egyéb speciális szükséglettel érkezők igényeinek. A konkrét kérdések a helyszínek akadálymentességre, az ételallergiával rendelkezők, valamint vegetáriánus és vegán látogatók számára elérhető kínálatra vonatkoztak. 


\subsubsection{Akadálymentesítés}

Mivel a rendezvények többnyire közterületen kerültek megrendezésre, az akadálymentesség biztosítása elsősorban nem a szervezők feladata volt, tehát a válaszok egy része arra utalt, hogy az adott városközpont, település alapvetően mennyire elérhető a mozgásukban valamilyen formában akadályozottak számára. A zárt térben zajló események kapcsán szintén maga a helyszín volt alapvetően akadálymentesített, így enne biztosítása nem jelentett külön feladatot a szervezők számára. Az egyik interjúalany azt is kiemelte, hogy a városi ivókutak is akadálymentesen megközelíthetők, így az ivóvízhez való hozzájutás sem jelentett akadályt. Azonban valamennyi szervező külön figyelmet fordít a kérdésre: „,Maximálisan odafigyelünk, ha bármilyen ilyen igény merül fel, bármilyen kérdésre személyesen válaszolunk." Egy másik válaszadó hangsúlyozta, hogy folyamatosan, „élö kapcsolat és egyeztetés volt végig a szervezés és lebonyolitás során az érdekvédelmi szervezetekkel."

A helyszínek adottságait is figyelembe véve a szervezők igyekeztek további lépéseket is tenni a programok hozzáférhetősége érdekében. Ilyen lépések volta a parkolás biztosítása, valamint székek kihelyezése a mozgásukban korlátozottak számára, illetve kisbusz üzemeltetése a településközpont és az egyik programhelyszín között, megkönnyítve ezzel az egyenetlen útburkolaton való közlekedést. A rendezvényhez biztosított mobil wc-k kihelyezésekor is gondoltak a potenciális mozgássérült látogatókra.

Ugyan a válaszok alapján a rendezvények hasonló módon törekedtek az akadálymentesség biztosítására, külön ki kell emelni a Veszprém-Balaton Filmpikniket, ahol a fizikai akadálymentesítésen túl a siketek és nagyothallók igényeire is odafigyelve, feliratozva vetítették a filmeket, az is előfordult, hogy ezt a szervezőknek kellett elkészítenie saját költségén: „,Sok filmforgalmazónak nem is volt felirata a filmekhez, a szervezöknek kellett legyártatni komoly összegért."

Mivel a három bemutatott rendezvény közül ez az EKF projekt egyetlen saját és újonnan indult rendezvénye, a projekt horizontális céljainak megfelelve az előkészítés és a lebonyolítás során rendszeresen konzultáltak az érintett érdekvédelmi szervezetekkel. A Filmpiknik kapcsán elhangzott olyan vélemény is, hogy ugyan fontos az akadálymentességet szem elött tartani, mindezt úgy kell megtenni, hogy ennek biztosítása nem hozzon létre esetlegesen egy olyan új akadályt, ami zavarhatja azon látogatók élményszerzését, akiknek nincs szüksége az akadálymentesítésre. Az interjúalany szavait idézve: “az akadálymentesités szenvedélye ne teremtsen újabb akadályokat azok számára, akiknek nincs szüksége akadálymentesitésre.” Itt elsősorban a filmekhez biztosított feliratok aprólékosságára utalt a válaszadó, például: „,minden zene még költőileg is körül volt irva (halk feszültségkeltö trombitaszó). Szerinte ,, a feliratozás aprólékossága helyenként zavarta a film élvezetét azok számára, akik nem az olvasáson keresztül jutottak a film élményhez."

\subsection{2 Ételallergia és speciális étkezési igények}

Az ételallergiával és speciális étkezési igényekkel rendelkezdő látogatók számára nyújtott kínálat kapcsán megoszlott a válaszadók véleménye. Volt olyan rendezvénygazda, aki úgy vélte, egy ingyenes és alapvetően nem gasztronómiai rendezvény esetében ez kevésbé hangsúlyos kérdés, nincs is igazi ráhatásuk a kínálatra: „A fellépők esetében tudjuk, hogy milyen kosztot akarnak, de a helyi és kiállitó vendéglátók kínálatát szervezöként nem befolyásoljuk, nem is tudjuk, hogy mi a palettájuk." A helyi és kitelepült vendéglátóipari szolgáltatók feladata, hogy odafigyeljen az ételallergiás és vegetáriánus vendégekre: „Ez a vendéglátósok feladata, ma már mindenki figyel az ételallergiás és vegetáriánus vendégekre” - mondta egy másik szervező. Hozzátette: „Többnyire helyi kézmüves ételek, italok vannak, nem az elöre elkészitett és lefagyasztott termékeket használják fel, hanem házilag elóállitott terméket”. 
Egy másik fesztiválgazda pedig úgy fogalmazott, hogy mivel az ételallergia korunk egyik fó problémája, mindenkinek feladata erre odafigyelni: „, A különleges étrenddel rendelkezö vendégek igényeinek kielégitése, egyre nagyobb elvárás ez a közönség részéröl, és tekintve, hogy általában drágábban lehet eladni ezeket az ételeket, a piac is motivált, hogy kielégítse ezeket az igényeket. Minden rendezvény kommunikációjában ki kell emelni, hogy ételallergiások, vegetáriánusok és vegánok számára milyen lehetöségeket kínálnak.” Az általa képviselt rendezvényen nagy hangsúly van a gasztronómiai kínálaton is, és bár nem az ő hatásköre a konkrét kínálat meghatározása, az ételallergiák és étkezési preferenciák figyelembevételét szempontként határozták meg a vendéglátó szolgáltatók számára. Ugyanezen rendezvényhez kapcsolódva megfogalmazódott olyan vélemény is, miszerint szervezési oldalról célszerübb a catering szolgáltatók kiválasztásánál néhány speciális étrendre szakosodott egységet is kiválasztani, mint minden egyes szolgáltató számára előírni, hogy feleljenek meg a speciális igényeknek is.

Egy másik rendezvény esetében pedig nem csak a látogatókra gondoltak, a szervező csapat, beleértve az önkéntes segítők körében is előre felmérték az étkezési igényeket, hogy a stáb számára is biztosítsák az esélyegyenlöséget ebben a tekintetben. Ezen rendezvény esetében a cateringet biztosító szolgáltatók a szabályozásnak megfelelően jelölték az allergén összetevőket az étlapokon: „A szolgáltatók fel voltak készülve erre, és információval is tudtak szolgálni a vendégeknek, hogy melyik ételben milyen allergén lehet. A bevont partnereink mind jelölik az allergéneket. A konferenciamenüt is ezek figyelembevételével állitották össze."

\section{Következtetések, javaslatok}

A fenntartható fejlődés gazdasági, társadalmi célkitűzéseinek szerves részét képezik az esélyegyenlőségi alapelvek, beleértve a valamilyen fogyatékossággal élők emberek számára a turisztikai és szabadidős szolgáltatásokhoz való hozzáférés biztosítása és az élményszerzés lehetőségének megteremtése (Darcy - Dickson (2009). A hozzáférés biztosítása a fizikai akadálymentesség megteremtésén túl az egyéb, fizikai vagy mentális fogyatékosságból, betegségből vagy állapotból fakadó speciális igények kielégítését is jelenti. A turisztikai szolgáltatók részéről ez nem csak erkölcsi kötelesség, kiváló üzleti lehetőség is egyben (Teixeira et al. 2019), hiszen a megfelelő feltétételek biztosításával a fogyasztók szélesebb körét tudják elérni, és bizonyos szolgáltatások esetében (mint például a speciális étrendre épülő ételkínálat) akár nagyobb haszonra is szert tehetnek. Mindezek tükrében javasolt fokozott figyelmet fordítani az akadálymentesítés különböző formáira, valamint a speciális igények kielégítésére, hiszen ez üzleti elönyt is jelenthet.

A Veszprém-Balaton 2023 Európa Kulturális Főváros projekt egyik horizontális célkitüzése az akadálymentesség biztosítása. A tanulmányban vizsgált három rendezvény közül kettő, a Köfeszt és az Utcazene Fesztivál (már korábban is megrendezésre kerültek) az EKF projekt támogatását élvezi, míg a Filmpiknik a VEB2023 első saját rendezvénye, így nem meglepő, hogy az akadálymentesség szempontként jelent meg a fesztiválok esetében. Ennek ismeretében érthető az is, hogy a saját rendezvényük esetében volt tapasztalható a legtöbb olyan kezdeményezés, amely a speciális igények kielégítésére a legnagyobb hangsúlyt helyezte. A válaszok alapján feltételezhető, hogy a helyszíni adottságok is valamelyest befolyásolják az esélyegyenlöség problémájának, beleértve az akadálymentesség problémájának az érzékelését az egyes rendezvényeken, hiszen a kisebb településeken megrendezett Köfeszten érezték kevesebben azt (42\%), hogy a probléma egyáltalán nincs jelen, a (fizikai) akadálymentességet eleve biztosító beltéri helyszíneken (közösségi térben, moziban) is zajló Filmpikniken pedig a legtöbben (56\%). Az akadálymentesítésre vonatkozóan érdekes válasz is megfogalmazódott, mely szerint arra is oda kell figyelni, hogy az akadálymentesítés biztosítása ne képezzen akadályokat azon látogatók számára, akiknek nincs szüksége az akadálymentesítést célzó szolgáltatásokra. 
Javasolt tehát a helyszín kiválasztásakor az akadálymentesség szempontjait is figyelembe venni, és amennyire lehet, a már akadálymentesített helyszíneket elönyben részesíteni, valamint az akadálymentesítés eszközeinél azokat választani, amik a legkevésbé vannak negatív hatással azon látogatók élményszerzésére, akiknek nincs szükségük az akadálymentesítést célzó szolgáltatásra.

Hazánkban az ételallergiával és egyéb speciális étkezési igényekkel rendelkező látogatók igényeinek kiszolgálása csak az elmúlt években került a figyelem középpontjába, így az ezzel kapcsolatos vélemények is megoszlanak a rendezvényszervezők között. Van, aki szervezőként nem a saját felelősségének gondolja a speciális étkezési igények kielégítését, míg mások szerint a szolgáltatók kiválasztásánál ez is fontos szempontként kell, hogy megjelenjen. Látogató oldalról azt tapasztaltuk, hogy az érintett válaszadók alapvetően meg voltak elégedve az ételkínálattal, föképp a gasztronómia kísérőrendezvényt is kínáló fesztiválon. Mivel az ételallergiával rendelkezők aránya 10\% körüli (a legtöbb kitöltést eredményező rendezvények pedig 15\% feletti) volt a vizsgált rendezvényeken, mindenképpen javasolt a speciális étkezési igényekre figyelmet fordítani. A speciális kínálatból nem csak az ételallergiások profitálhatnak, az allergiával nem rendelkező egészségtudatos látogatók számára is a kínálat bővülését jelenti ez a törekvés, a szolgáltató számára pedig potenciálisan nagyobb hasznot és versenyelőnyt jelent. A speciális kínálat biztosításakor pedig érdemes megfogadni az egyik interjúalany rendezvényszervező ajánlását, hogy célszerü eleve speciális ételkínálattal jelentkező catering szolgáltatókat (is) választani, mint minden egyes szolgáltatóra ráerőltetni egy ilyen kényszert, még ha nincs is felkészülve ennek a biztosítására.

Összegezve elmondható, hogy minden olyan törekvés, ami a turisztikai szolgáltatásokhoz, attrakciókhoz, szabadidős élményszerzéshez való hozzáférés lehetőségét bővíti, szélesíti a turizmusban részt vevő szegmensek körét, így üzleti potenciál is rejlik benne, valamint a társadalmi felelösségvállalás eszközének is tekinthető.

\section{Köszönetnyilvánítás}

Jelen publikáció a Nemzeti Kutatási, Fejlesztési és Innovációs Hivatal által biztosított forrásból a 2019-1.3.1-KK-2019-00015 azonosító számú, „Körforgásos gazdasági alapokon nyugvó fenntarthatósági kompetencia központ létrehozása a Pannon Egyetemen" című projekt keretében jött létre.

\section{Irodalomjegyzék}

BENEDÉ, S. - BLÁZQUEZ, A.B. - CHIANG, D. - TORDESILLAS, L. - BERIN, M.C. (2016): The rise of food allergy: Environmental factors and emerging treatments. EBioMedicine 7: pp 2734. DOI: 10.1016/j.ebiom.2016.04.012

BUHALIS, D. - MICHOPOULOU, E. (2013): Information provision for challenging markets: The case of the accessiblity requiring market in the context of tourism. Information and Management 50: pp. 229-239. DOI: 10.1016/j.im.2013.04.001

Darcy, S. (2010): Inherent complexity: disability, accessible tourism and accommodation information preferences. Tourism Management 30: pp. 816-826.

DOI: $10.1016 /$ j.tourman.2009.08.010

DARCY, S. - DICKSON, T. J. (2009): A whole-of-life approach to tourism: The case for accessible tourism experiences. Journal of Hospitality and Tourism Management 16: pp. 32-44. DOI:10.1375/jhtm.16.1.32

DWYER, L. - DARCY, S. (2011): Economic Contribution of Tourists with Disabilities: An Australian Approach and Methodology. In BUHALIS, D. - DARCY, S. (Eds.), Accessible Tourism Concepts and Issues (pp. 213-239). Channel View Publications.

EREN, S. (2020): Food-related barriers to gastronomy and tourism: The role of food allergies and diet preferences. Manas Sosyal Araştırmalar Dergisi, 9(2), pp. 1117-1129. DOI: $10.33206 / \mathrm{mjss} .560570$ 
European Commission (2013): EU Study, Economic Impact and Travel Patterns of Accessible Tourism in Europe. European Commission, Brussels.

FARKAS, J. - PETYKÓ, Cs. (2020): Disability, accessibility, and mobility as basic existential characteristics. In Schmidtchen, R. and Gonda, T. (eds): Opportunities and challenges of barrierfree tourism in Hungary Results and Recommendations of a scientific workshop during the conference "European Peer-Counselor Training in Accessible Tourism - Peer-AcT" on September 4, 2020. Orfü (Hungary): pp. 89-99.

GILlOVICH, B. - MCINTOSH, A. (2020): Accessibility and Inclusive Tourism Development: Current State and Future Agenda. Sustainability 12: pp. 9722. DOI:10.3390/su12229722

GONDOS, B. (2020): Speciális igények a turizmusban - A mozgáskorlátozottak helye szerepe, és lehetősége a turisztikai szektorban. Széchenyi István Egyetem, Győr.

IKIZ, A. N. - SOLUNOGLU, A. (2018): Attitudes and Practices Towards Vegetarian Foods in Hotels. Journal of Tourism and Gastronomy Studies, 6(3), pp. 14-25. DOI: 10.21325/jotags.2018.235

Kastenholz, E. - Eusebio, C. - Figueiredo, E. (2015): Contributions of tourism to social inclusion of persons with disability. Disability and Society 30(8): pp. 1259-1281. DOI:10.1080/09687599.2015.1075868

LEE, Y. M. - SOZEN, E. (2016): Food allergy knowledge and training among restaurant employees. International Journal of Hospitality Management, 57, pp. 52-59. DOI:10.1016/j.ijhm.2016.05.004

LEIDNER, R. - BENDER, M. (2007): The European Tourism Industry in the Enlarged Community, Gaps are Potentials and Opportunities. European Commission, Brussels.

LORGER, R. - ZSARNÓCZKY, M. (2019): Mentesség vizsgálata a budapesti vendéglátóipar kínálatában. In: LX. Georgikon Napok nemzetközi tudományos konferencia kötete. Pannon Egyetem, Keszthely. pp. 5553-561. https://napok.georgikon.hu/hu/

LÖRINCZ, K. (2017): A fenntarthatóság társadalmi vetületei az Európai Kulturális Főváros projektben. Comitatus különszám, pp 64-72

LŐRINCZ, K. - RAFFAY, Á. (2019): Beyond, azaz túllépni saját magunkon - a turizmus szerepe a Veszprém2023 Európai Kulturális Főváros projektben. Turisztikai és Vidékfejlesztési Tanulmányok 4(2): pp. 18-38. DOI: 10.15170/TVT.2019.04.02.02

Mckercher, B. - Darcy, S. (2018): Re-conceptualizing barriers to travel by people with disabilities. Tourism Management Perspectives 26: pp. 59-66. DOI: 10.1016/j.tmp.2018.01.003.

PRATTEN, J. - TOWERS, N. (2004): Food allergies and the UK catering industry. A study of the training needs for the industry to serve those with food allergies. Journal of European Industrial Training. Vol. 28. No. 6, pp. 490-498. DOI:10.1108/03090590410542710

RAFFAY, Z. - GONDA, T. (2020): Accessible tourism in some European countries - results of an empirical survey. In Schmidtchen, R. and Gonda, T. (eds): Opportunities and challenges of barrierfree tourism in Hungary. Results and Recommendations of a scientific workshop during the conference "European Peer-Counselor Training in Accessible Tourism - Peer-AcT" on September 4, 2020. Orfü (Hungary). pp. 23-52.

SALKOVA, D. - TICHA, L. (2020): Food intolerance and customer behavior specifics as a limiting factor for travelling. Deturope-The Central European Journal of Regional Development and Tourism, Vol. 12 Issue 1, pp. 119-135 http://www.deturope.eu/img/upload/Salkova.pdf SHAW, G. - COLES, T. (2004): Disability, holiday making and the tourism industry in the UK: a preliminary survey. Tourism Management 25: pp. 397-403. DOI: 10.1016/S0261-5177(03)001390

SVERKER, A. - HENSING, G. - HALLERT, C. (2005). 'Controlled by food'-lived experiences of coeliac disease. Journal of Human Nutrition and Dietetics, 18(3), pp. 171-180. DOI:10.1111/j.1365-277X.2005.00591.x. 
TEIXEIRA, L. - EUSEBIO, C. - SILVEIRO, A. (2019): Websites accessibility of Portuguese travel agents: a view using web diagnostic tools. Proceedings of the 14th Iberian Conference on Information Systems and Technologies (CISTI), Coimbra, Portugal, 12-22 June. DOI:10.23919/CISTI.2019.8760949

ZHELYAZKOVA, I. - YARKOVAL, Y. - ZHELEVA, A. (2007): Tourism for handicapped people responsibility and commitment in the period of Bulgaria's accession to the European Union. Trakia Journal of Sciences, Vol. 4 No. 4, pp. 39-43.

ZSARNÓCZKY, M. (2018): The Future Challenge of Accessible Tourism in the European Union. Vadyba Journal of Management 2(33): pp. 39-43.

\section{Egyéb források}

Köfeszt (2019): Kőfeszt. Kövágóörsi Müvészeti Napok. A nyugalom fesztiválja. https://www.kofeszt.hu/pages/kmn/contents/media/32/31856/ko-feszt-a-nyugalom-fesztiva-lja2019.pdf, letöltve: 2021. 02. 20.

Köfeszt (2020): Kőfeszt. A nyugalom fesztiválja. 2019/2020 összefoglaló. https://www.kofeszt.hu/pages/kmn/contents/media/161/160589/kofeszt_osszefoglalo_2020.pdf, letöltve: 2021. 02. 22.

Medicalonline (2017): Ötmillió túlsúlyos és hárommillió ételallergiás. http://medicalonline.hu/eu_gazdasag/cikk/otmillio_tulsulyos_es_harommillio_etelallergias, letöltve: 2020. 03. 24.)

Plant Menu, https://www.limevenueportfolio.com/content-hub/beyond-food-reports/plant-menu/ letöltve 2021. 02. 04.

https://filmpiknik.hu/akadalymentesseg, letöltve 2021.01.21. 